\title{
Dexmedetomidine sedation in a pediatric cardiac patient scheduled for MRI
}

\author{
[Sédation avec dexmédétomidine chez une enfant devant subir un examen d'IRM]
}

Elizabeth T. Young MD

Purpose: To describe the use of dexmedetomidine for sedation in a critically ill infant undergoing magnetic resonance imaging (MRI).

Clinical features: A nine-month-old $5.1 \mathrm{~kg}$ infant was to have an MRI study of the thorax. The infant had multiple congenital cardiac anomalies which had been partially corrected surgically. After administration of atropine, $0.1 \mathrm{mg}$ iv, a loading dose of dexmedeto-

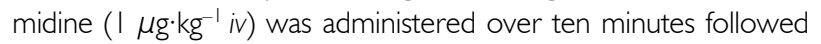
by a continuous infusion of $0.5 \mu \mathrm{g} \cdot \mathrm{kg}^{-1} \cdot \mathrm{hr}^{-1}$ for maintenance. Propofol $5 \mathrm{mg}$ iv were administered after the loading dose of dexemedetomidine to produce somnolence. Anesthetic conditions for performing the MRI were excellent. The infant remained motionless, breathing spontaneously. Hemodynamics remained stable throughout the procedure. Recovery was rapid and uneventful.

Conclusion: Dexmedetomidine and a small dose of propofol were used successfully to sedate a critically ill infant for MRI. More studies are required to determine the role of this unique drug in the pediatric population.

Objectif : Décrire l'usage de dexmédétomidine pour la sédation d'une enfant gravement malade devant subir un examen d'imagerie par résonance magnétique (IRM).

Éléments cliniques : Une enfant de 9 mois, pesant $5,1 \mathrm{~kg}$, devait subir un examen du thorax par IRM. Elle avait de multiples anomalies cardiaques congénitales, partiellement corrigées chirurgicalement. Après l'administration iv de 0,I mg d'atropine, une dose de charge de dexmédétomidine ( $\left.\mathrm{Mg}_{\mathrm{kg}}{ }^{-1} \mathrm{iv}\right)$ a été administrée pendant $10 \mathrm{mi}$ nutes, suivie d'une perfusion continue de maintien de $0,5 \mu \mathrm{g} \cdot \mathrm{kg}^{-1} \cdot \mathrm{h}^{-1}$. Après la dose de charge de dexmédétomidine, $5 \mathrm{mg}$ de propofol iv ont été administrés pour produire la somnolence. Les conditions anesthésiques étaient excellentes pour réaliser l'IRM. L'enfant est demeurée immobile et respirait spontanément. L'hémodynamique a été stable tout au long de l'examen. La récupération a été simple et rapide.
Conclusion : La dexmédétomidine et une petite dose de propofol ont été utilisées avec succès pour la sédation pendant l'IRM chez une enfant gravement malade. II reste à déterminer le rôle de ce médicament particulier chez la population pédiatrique.

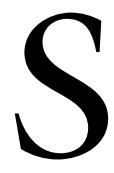

EDATING children for magnetic resonance imaging (MRI) poses many challenges due to the effects of the magnetic field. MRI sedation for small critically ill infants may require general anesthesia and controlled ventilation. ${ }^{1}$ Dexmedetomidine, an alpha- ${ }_{2}$ adrenergic agonist, has been used to provide sedation and analgesia postoperatively in surgical patients with minimal effect on respiration. ${ }^{2}$ This case report describes a small infant with complex congenital heart disease (CHD) who received $i v$ dexmedetomidine and propofol for MRI sedation while breathing spontaneously.

\section{Case report}

A nine-month-old, $5.1-\mathrm{kg}$ infant was scheduled for MRI of the thorax under anesthesia. Medical history revealed a double outlet right ventricle and mitral atresia with single ventricle physiology. Initial surgical correction as a neonate consisted of placement of a Blalock-Taussig shunt. At age six months, the BlalockTaussig shunt was revised and a bi-directional Glenn shunt was placed. The infant had a history of persistent bilateral chylous pleural effusions, which had been drained by computed tomography-assisted thoracentesis and chest tube placement. Small bilateral pleural effusions were present on chest radiograph. Recent cardiac catheterization demonstrated increased pulmonary artery pressure and possible pulmonary

From the Department of Anesthesiology, Ochsner Clinic Foundation, New Orleans, Louisiana, USA.

Address correspondence to: Dr. Elizabeth T. Young, Ochsner Clinic Foundation, 1514 Jefferson Highway, New Orleans, LA 70121, USA.

Phone 504-842-3755; Fax 504-842-2036; E-mail: Eyoung@ochsner.org

There is no conflict of interest to disclose.

Accepted for publication November 3, 2004.

Revision accepted March 4, 2005. 
venous stenosis. MRI of the thorax was requested to further evaluate patency of the pulmonary venous system, a necessary condition for future consideration as a heart transplant recipient.

Physical examination in the MRI suite revealed an alert infant, with a functioning peripheral $i v$ line, receiving $0.5 \mathrm{~L} \cdot \mathrm{min}^{-1}$ supplemental oxygen via nasal cannula. Vital signs were: respiratory rate 25 breaths $\mathrm{min}^{-1}$, blood pressure $75 / 38 \mathrm{mmHg}$ measured by cuff on the left thigh, heart rate 125 beats. $\mathrm{min}^{-1}$, oxygen saturation $82 \%$. After pretreatment with atropine $0.1 \mathrm{mg} i v$, a dexmedetomidine loading dose of $1 \mu \mathrm{g} \cdot \mathrm{kg}^{-1}$ iv was administered over ten minutes. At this point, $5 \mathrm{mg}$ of $i v$ propofol were administered to produce somnolence as the infant occasionally cried. A dexmedetomidine infusion of $0.5 \mu \mathrm{g} \cdot \mathrm{kg}^{-1} \cdot \mathrm{hr}^{-1}$ was started, and the infant was positioned in the MRI scanner. Oxygen at $4 \mathrm{~L} \cdot \mathrm{min}^{-1}$ was administered by pediatric face mask with an endtidal $\mathrm{CO}_{2}$ sampling port affixed inside the mask. Soft foam ear muffs with adhesive backing were applied to abate noise from the MRI machine. Anesthetic conditions were excellent, with minimal change in vital signs during the entire $30 \mathrm{~min}$ duration of the scan. End-tidal $\mathrm{CO}_{2}$ was initially $54 \mathrm{mmHg}$ and stayed in the mid 50 range throughout the procedure. Once during the scan, the supplemental oxygen supply became accidentally disconnected from its source. Oxygen saturation briefly fell to $84 \%$, similar to preoperative values, then rose again to $94 \%$ when oxygen was reconnected. Once the scan was completed, the infant was awake and responsive to light tactile stimulation within five minutes after the dexemedetomidine infusion was discontinued. Recovery was uneventful.

\section{Discussion}

Dexmedetomidine is an alpha- ${ }_{2}$ adrenergic agonist with sedative, analgesic, and anxiolytic properties similar to clonidine, another alpha- ${ }_{2}$ agonist. ${ }^{3,4}$ Dexmedetomidine has seven times the alpha- ${ }_{2}$ receptor specificity of clonidine; and is only available as a readily titratable $i v$ drug with rapid onset. Its pharmacology and mechanism of action have been reviewed elsewhere. ${ }^{5}$ Briefly, alpha- ${ }_{2}$ receptors modulate the activity of the autonomic nervous and cardiovascular systems. Activation of the alpha- ${ }_{2}$ receptor in peripheral blood vessels causes vasoconstriction and, in the autonomic ganglia, stimulation of the receptor inhibits the release of catecholamines. ${ }^{5,6}$ Activation of alpha- ${ }_{2}$ receptors in the central nervous system, particularly in the locus ceruleus, may cause a significant reduction in central sympathetic flow and result in sedation and increased vagal activity. ${ }^{7-9}$ Sedation with dexemedetomidine resembles light sleep. In contrast to other hypnotics, such as propofol, sedation with alpha- ${ }_{2}$ agonists causes minimal respiratory depression and has little effect on the ventilatory response to an inhaled carbon dioxide challenge. ${ }^{8,9}$

Dexmedetomidine is currently approved only for short-term $(24 \mathrm{hr})$ sedation in intubated and mechanically ventilated adults in the intensive care unit. Experience with the use of dexmedetomidine in pediatric patients has been limited. In one study, sedation with a continuous infusion of dexemedetomidine at 0.25 $\mu \mathrm{g} \cdot \mathrm{kg}^{-1} \cdot \mathrm{hr}^{-1}$ was comparable to midazolam 0.22 $\mathrm{mg} \cdot \mathrm{kg}^{-1} \cdot \mathrm{hr}^{-1}{ }^{6}$ At higher infusion rates $\left(0.5 \mu \mathrm{g} \cdot \mathrm{kg}^{-1} \cdot \mathrm{hr}^{-1}\right)$, sedation with dexemedetomidine was reported to be superior to midazolam, as measured by morphine requirements during the case. ${ }^{6}$ Of interest, these authors indicated that dexemedetomidine was less effective as a sedative in infants less than 12 months of age. ${ }^{6}$ This may be the reason why we needed to administer a small dose of propofol to produce somnolence in our infant. In a separate report, the same authors described a case of severe bradycardia ( 54 beats. $\mathrm{min}^{-1}$ ) in a five-week-old infant $(3.6 \mathrm{~kg})$, who was also receiving digoxin, after 13 $\mathrm{hr}$ of constant rate infusion of dexemedetomidine, 0.5 $\mu \mathrm{g} \cdot \mathrm{kg}^{-1} \cdot \mathrm{hr}^{-1} .{ }^{10}$ The authors speculated that a potential interaction between digoxin and dexemedetomidine may cause bradycardia. Nonetheless, because of the potential for increased cardiac activity with dexemedetomidine, we opted to pretreat the infant with atropine. It is important to note that the doses of dexemedetomidine required for sedation in pediatric patients are considerably lower than for adult patients, where the loading dose is typically 1 $\mu \mathrm{g} \cdot \mathrm{kg}^{-1}$ followed by an infusion of 0.2 to 0.7 $\mu \mathrm{g} \cdot \mathrm{kg}^{-1} \cdot \mathrm{hr}^{-1}$.

No previous reports describe the use of dexemedetomidine as a sedative in infants with CHD who are not intubated and mechanically ventilated. MRI scans are not particularly stimulating procedures but do require the patient to remain perfectly still in order to obtain a good quality study. At our institution, the usual technique for sedating pediatric patients requiring anesthesia for an MRI would have been a propofol infusion with controlled ventilation. By using dexmedetomidine, we were able to maintain spontaneous ventilation during sedation which greatly simplified the anesthetic technique because of the magnetic fields related to MRI. No respiratory depression was detected, consistent with what has been observed with the use of dexmedetomidine in adults. ${ }^{7}$ It is nevertheless possible that we under-appreciated the potential for respiratory depression for two reasons. First, we measured $\mathrm{ETCO}_{2}$ by a catheter placed in the mask. Measuring carbon dioxide using this technology may be affected by the flow rate of oxygen, turbulence under the mask, and 
leaks. Secondly, this infant had congenital cardiac lesions which may make it difficult to predict the true end-tidal to arterial carbon dioxide tension. However, other parameters of respiratory function were satisfactory. For instance, oxygen saturation was well maintained throughout, even with an inadvertent interruption in supplemental oxygen supply to the infant, and respiratory rate remained normal.

Anesthetic goals were accomplished with dexmedetomidine due to its unique pharmacology. Under the described conditions, dexmedetomidine infusion and a small initial dose of propofol provided excellent anesthetic conditions for an MRI procedure in a critically ill child. More studies are required to determine the utility of dexmedetomidine as a sedative for non-stimulating procedures in children.

\section{References}

1 Coté CJ. Anesthesia outside the operating room. In: Coté CJ, Todres ID, Ryan JF, Goudsouzian NG (Eds). A Practice of Anesthesia for Infants and Children, 3rd ed. Philadelphia: W.B. Saunders; 2001: 571-83.

2 Herr DL, Sum-Ping ST, England M. ICU sedation after coronary artery bypass graft surgery: dexmedetomidine-based versus propofol-based sedation regimens. J Cardiothorac Vasc Anesth 2003; 17: 576-84.

3 Kamibayashi T, Maze M. Clinical uses of alpha ${ }_{2}$-adrenergic agonists. Anesthesiology 2000; 93: 1345-9.

4 Khan ZP, Ferguson CN, Jones RM. Alpha-2 and imidazoline receptor agonists. Their pharmacology and therapeutic role. Anaesthesia 1999; 54: 146-65.

5 Scheinin H, Karbuvaara S, Olkkola KT, et al. Pharmacodynamics and pharmacokinetics of intramuscular dexmedetomidine. Clin Pharmacol Ther 1992; 52: 537-46.

6 Tobias JD, Berkenbosch JW. Initial experience with dexmedetomidine in paediatric-aged patients. Paediatr Anaesth 2002; 12: 171-5.

7 Venn RM, Hell J, Grounds RM. Respiratory effects of dexmedetomidine in the surgical patient requiring intensive care. Crit Care 2000; 4: 302-8.

8 Nelson LE, Lu J, Guo T, Saper CB, Franks NP, Maze M. The alpha $a_{2}$-adrenoceptor agonist dexmedetomidine converges on an endogenous sleep-promoting pathway to exert its sedative effects. Anesthesiology 2003; 98: 428-36.

9 Tobias JD, Berkenbosch JW. Sedation during mechanical ventilation in infants and children: dexmedetomidine versus midazolam. South Med J 2004; 97: 451-5.

10 Berkenbosch JW, Tobias JD. Development of bradycardia during sedation with dexmedetomidine in an infant concurrently receiving digoxin. Pediatr Crit Care Med 2003; 4: 203-5. 